\title{
Simplified Internal Model Control and its Applications to Sensorless Grasping Control
}

\author{
Ryoichi Suzuki Non-member (Kanazawa Institute of Technology) \\ Kouhei Itou Non-member (Kanazawa Technical College) \\ Akira Sugawara Non-member (Sohgo Security Services Co., Ltd) \\ Nobuaki Kobayashi Non-member (Kanazawa Institute of Technology) \\ Yoshinori Takei Member (Kanazawa Institute of Technology)
}

Keywords : Internal model control, Reduction of controller, Unknown input estimation, State estimation, Grasping control

A simplified IMC scheme is proposed in this paper. By using an inverse system or an approximate inverse system for the IMC structure, the order of the controller leads the high order, meanwhile the high order controller is not practical in implementation. This paper is concerned with the problem of reducing a high order controller to reduced order one. The disturbance estimation property of the closed loop system is also discussed. The proposed procedure is applied to prototype robotic

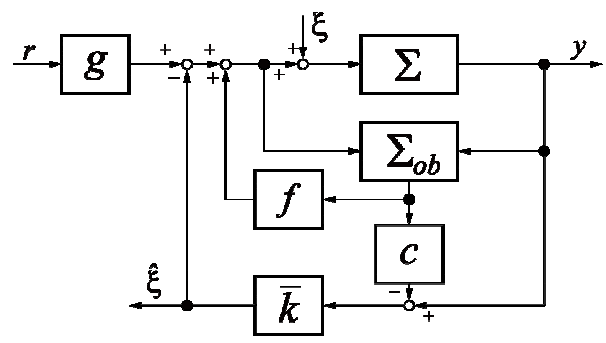

Fig. 1. Proposed controller structure
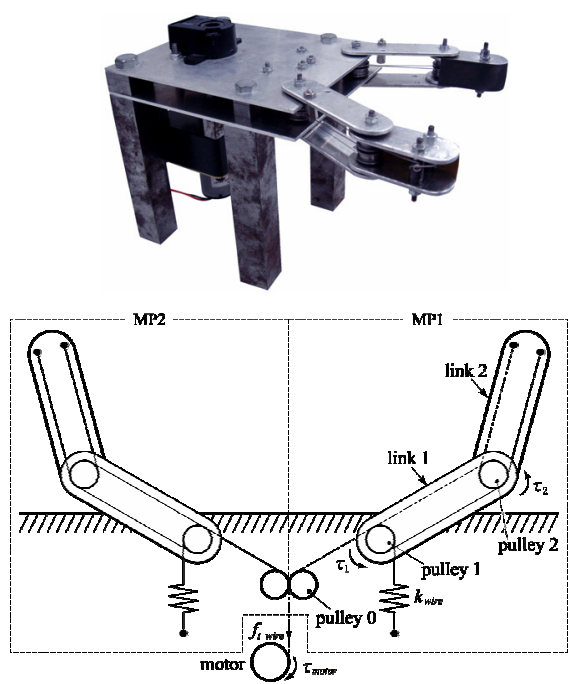

Fig. 2. Robotic hand with two fingers hand that can hold an object with suitable grasping force without force sensor. The effectiveness of the proposed controller scheme is confirmed by experiments.

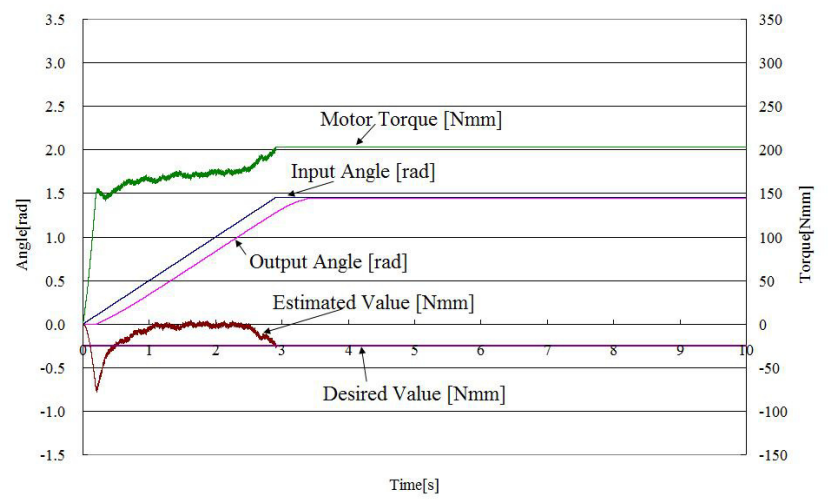

Fig. 3. Experimental result

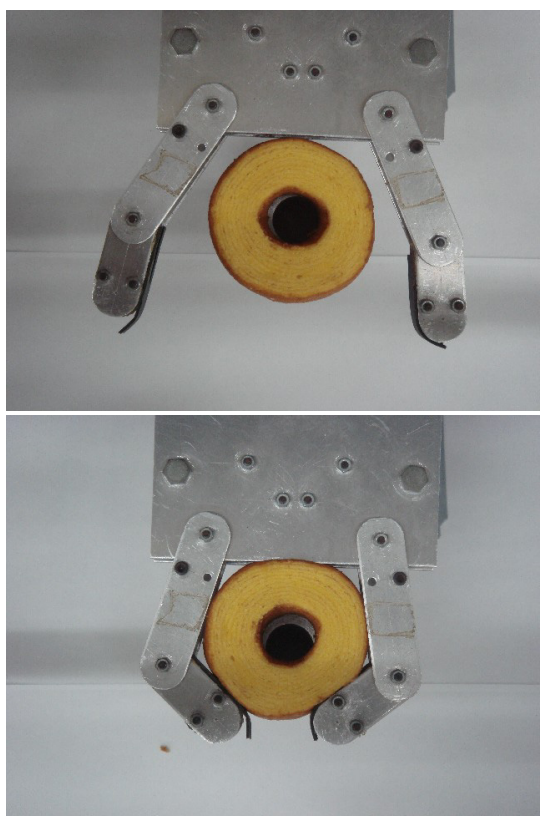

Fig. 4. Successful result 


\title{
簡易型内部モデル制御の構成法と把持力制御への応用
}

\author{
非会員 鈴木 亮一 $*$ 非会員 伊藤 恒平** \\ 非会員菅原映*** 非会員 小林 伸明* \\ 正 員 竹井 義法*
}

\begin{abstract}
Simplified Internal Model Control and its Applications to Sensorless Grasping Control
Ryoichi Suzuki*, Non-member, Kouhei Itou**, Non-member, Akira Sugawara***, Non-member, Nobuaki Kobayashi*, Non-member, Yoshinori Takei*, Member
\end{abstract}

\begin{abstract}
A simplified IMC scheme is proposed in this paper. By using an inverse system or an approximate inverse system for the IMC structure, the order of the controller leads the high order, meanwhile the high order controller is not practical in implementation. This paper is concerned with the problem of reducing a high order controller to a reduced order one. The disturbance estimation property of the closed loop system is also discussed. The proposed procedure is applied to prototype robotic hand that can hold an object with suitable grasping force without force sensor. The effectiveness of the proposed controller scheme is confirmed by experiments.
\end{abstract}

Keywords: Internal model control, Reduction of controller, Unknown input estimation, State estimation, Grasping control

\section{1. はじめに}

プロセス制御などに利用されている内部モデル制御は, Horowiz P Morari らによって提案され, 研究が進められ てきた制御方法で, 制御対象に制御対象のモデルを並列に 接続し, 両者の出力誤差をコントローラに通しフィードバッ クする制御方法である(1)。Zhou らは，内部モデル制御の外 側にループを施しロバスト性を有する制御系を提案し, こ れを一般化内部モデル制御 (GIMC) と呼んでいる ${ }^{(2)}$ 。

内部モデル制御の一つの特徴として，コントローラにモ デルの近似逆系を使うことで未知入力 (外乱)を新たなセン サを必要とせずに再構成でき，これを種々な制御に利用で きる点にある。この特徵を利用して再構成した外乱を入力

\footnotetext{
* 金沢工業大学

† 921-8501 石川県石川郡野々市町扇が丘 7-1

Kanazawa Institute of Technology

7-1, Nonoichi, Ishikawa 921-8501

** 金沢工業高等専門学校

干 921-8601 石川県金沢市久安 2-270

Kanazawa Technical College

2-270 Hisayasu Kanazawa, Ishikawa 921-8601

*** 綜合警備保障 (株)

广 107-8511 東京都港区元赤坂 1-6-6

Sohgo Security Services Co., Ltd.

1-6-6 Motoakasaka, Minatoku, Tokyo 107-8511
}

に加え, 入力端に加わる外乱と相殺して目標追従性を高め ている。未知入力 (外乱) の推定值を利用した応用にはマス ター, スレーブのバイラテラルサーボに応用した研究報告 もあるが, 未知入力の推定值を利用した応用事例は比較的 少ない。また, 内部モデル制御は, 制御対象のモデルを内 蔵するため, 制御対象が安定であるか, 状態を用いて安定 化できる必要があり, かつ, コントローラの次数が増大し てしまう。これらの欠点を解決する手法もいくつか提案さ れてはいるが, 両方を満足する方法は示されていない。

本論文では, 未知入力 (外乱) の推定が可能な低次元内部 モデル制御の簡易設計手順を導入し，この手法をオブザー バにもとづく一般化安定化補償器による制御に展開し, 新 しい簡易な設計法を提案し, 得られる制御系が外乱の推定 と抑制という内部モデル制御固有の特徵をもつことを示す。 さらに, 推定した外乱を積極的に利用する例として, 力セ ンサを使用しないワイヤ駆動のハンドによる把持力制御に 応用し，提案する制御系の有効性を検証する。

\section{2. 未知入力 (把持力) の推定と状態推定の基本理論}

$\langle\mathbf{2} \cdot \mathbf{1}\rangle$ 内部モデル制御の概要と問題点 つぎの 1 入 力 1 出力系で, 入力端に外乱の加わるシステム

$$
\begin{aligned}
& \dot{\boldsymbol{x}}=A \boldsymbol{x}+\boldsymbol{b} u+\boldsymbol{b} \xi \\
& y=\boldsymbol{c} \boldsymbol{x}
\end{aligned}
$$


を考える。 $\boldsymbol{x} \in \mathbb{R}^{n}$ は状態ベクトル $, u \in \mathbb{R}^{1}, y \in \mathbb{R}^{1}$ は 入力, 出力で, システムは可制御, 可観測である。 $\xi は \mathbb{R}^{1}$ の未知入力で, 後に応用する把持機構においては把持した 際の把持物体からの反力がこれにあたる。

上述のシステムの把持力制御システムを考える前に, こ のようなシステムに対して, 状態 $\boldsymbol{x}$ が既知の場合，あるい は未知の場合に，把持の際に生じる反力 (未知入力) を推定 する機能を持つシステムを構成することを考える。未知入 力は比較的低周波数のものであるとして, 問題は前述した ように内部モデル制御と同等の未知入力推定機能を有する 低次元のコントローラの構成法を示すことである。

(1) のシステムに最適レギュレータ問題の解である状態 フィードバック

$$
\begin{aligned}
& u=\boldsymbol{f} \boldsymbol{x} \quad \boldsymbol{f}=-\gamma^{-1} \boldsymbol{b}^{T} P \\
& P A+A^{T} P-\gamma^{-1} P \boldsymbol{b} \boldsymbol{b}^{T} P+\boldsymbol{c}^{T} \boldsymbol{c}=\mathbf{0}
\end{aligned}
$$

を施した閉ループ系について，つぎの補題が知られている。

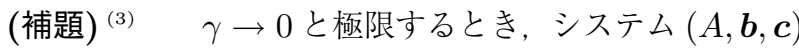
の不変零点がすべて負であれば,

$$
\lim _{\gamma \rightarrow 0} \boldsymbol{c}(s I-A-\boldsymbol{b} \boldsymbol{f})^{-1} \boldsymbol{b} \rightarrow 0 .
$$

が成立し，閉ループ極は等価零点に漸近するものと，残り は実部が負の無限遠点となる。

このフィードバックループを取り込んだシステム $\Sigma_{f}$ は

$$
\Sigma_{f}: \begin{aligned}
& \dot{\boldsymbol{x}}=(A+\boldsymbol{b} \boldsymbol{f}) \boldsymbol{x}+\boldsymbol{b} v+\boldsymbol{b} \xi \\
& y=\boldsymbol{c} \boldsymbol{x}
\end{aligned}
$$

であるから，フィードバック系 $\Sigma_{f}$ とした内部モデル制御 のブロック線図は次の Fig.1 となる。

$\Sigma_{f}$ と内部モデル $\bar{\Sigma}_{f}$ の誤差システム $\Sigma_{e}$ は

$$
\Sigma_{e}: \begin{aligned}
& \dot{e}=(A+\boldsymbol{b} \boldsymbol{f}) \boldsymbol{e}+\boldsymbol{b} \xi \\
& \eta=\boldsymbol{c e}
\end{aligned}
$$

であるから，この拡大系の状態方程式表現はつぎのように 書ける。

$$
\begin{aligned}
\left(\begin{array}{c}
\dot{\boldsymbol{x}} \\
\dot{e} \\
\dot{\mu}
\end{array}\right)= & \left(\begin{array}{ccc}
A+\boldsymbol{b} \boldsymbol{f} & -\boldsymbol{b} d_{Q} \boldsymbol{c} & -\boldsymbol{b} \boldsymbol{c}_{Q} \\
\mathbf{0} & A+\boldsymbol{b f} & \mathbf{0} \\
\mathbf{0} & \boldsymbol{b}_{Q} \boldsymbol{c} & A_{Q}
\end{array}\right)\left(\begin{array}{c}
\boldsymbol{x} \\
\boldsymbol{e} \\
\boldsymbol{\mu}
\end{array}\right) \\
& +\left(\begin{array}{c}
\boldsymbol{b} \\
\boldsymbol{b} \\
\mathbf{0}
\end{array}\right) \xi+\left(\begin{array}{l}
\boldsymbol{b} \\
\mathbf{0} \\
\mathbf{0}
\end{array}\right) v \ldots \ldots \ldots . \\
y= & \left(\begin{array}{lll}
\boldsymbol{c} & \mathbf{0} & \mathbf{0}
\end{array}\right)\left(\begin{array}{c}
\boldsymbol{x} \\
\boldsymbol{e} \\
\boldsymbol{\mu}
\end{array}\right)
\end{aligned}
$$

ただし $\left(A_{Q}, \boldsymbol{b}_{Q}, \boldsymbol{c}_{Q}, d_{Q}\right)$ は $\Sigma_{e}$ の近似逆系 $\Sigma_{e \tau}^{-1}$ で

$$
\Sigma_{e \tau}^{-1} \Sigma_{e}=(\tau s+1)^{-d}
$$

となるシステムの最小実現であり,$d$ は $\Sigma_{e \tau}^{-1}$ をプロパーと

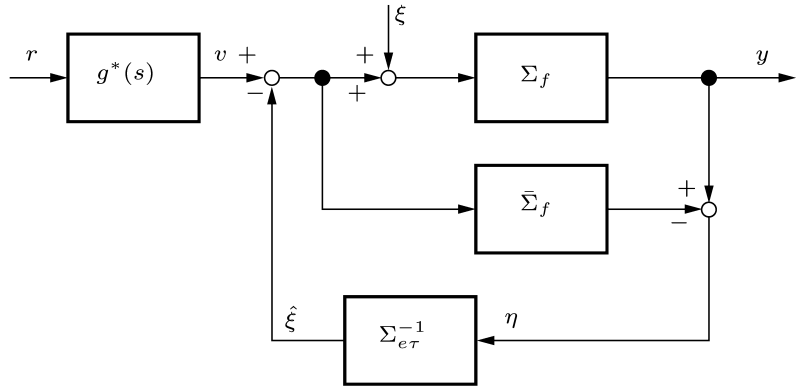

Fig. 1. Internal Model Control with Approximate Inverse System

する指数である。また $\mu$ は近似逆系の内部変数である。

このように状態が既知の場合, フィードバックと内部モ デル制御の併用系について，つぎのような特性が成立して いる。

(フィードバック併用内部モデル制御の特性）＼cjkstart最適レ ギュレータによるフィードバックと内部モデル併用系は相 乗的外乱抑制効果により $\gamma \rightarrow 0, \tau \rightarrow 0$ に打いて目標值追 従性を向上させる。また, 逆システムの出力端で $\hat{\xi} は \xi を$ $\tau \rightarrow 0$ の極限で再構成する。

これは出力 $y$ のラプラス変換 $Y(s)$ が

$$
Y(s)=H_{y v}(s) v(s)+H_{y \xi} \xi(s)
$$

であり, 各々 $H_{y v}(s), H_{y \xi}(s), v(s)$ はつぎのように与えら れる。

$$
\begin{aligned}
H_{y v}(s)= & \boldsymbol{c}(s I-A-\boldsymbol{b} \boldsymbol{f})^{-1} \boldsymbol{b} \\
H_{y \xi}(s)= & {\left[1-\boldsymbol{c}(s I-A-\boldsymbol{b} \boldsymbol{f})^{-1} \boldsymbol{b}\right.} \\
& \left.\left\{\boldsymbol{c}_{Q}\left(s I-A_{Q}\right)^{-1} \boldsymbol{b}_{Q}+d_{Q}\right\}\right] \\
& \boldsymbol{c}(s I-A-\boldsymbol{b} \boldsymbol{f})^{-1} \boldsymbol{b} \ldots \ldots .
\end{aligned}
$$

また, $v(s)=g^{*}(s) r$ とし $g^{*}(s)$ を次のように選定する と, 次の (8) 式，(9) 式の特性をそれぞれ得る。つまり, $g^{*}(s) ; \bar{\Sigma}_{f}$ の近似逆系と選定するとき

$$
\lim _{\tau \rightarrow 0} H_{y r}(s)=1
$$

$g^{*}(s)$; 定数 $g=\left\{\boldsymbol{c}(-A-\boldsymbol{b} \boldsymbol{f})^{-1} \boldsymbol{b}\right\}^{-1}$ と選定するとき

$$
\lim _{s \rightarrow 0} \boldsymbol{c}(-A-\boldsymbol{b} \boldsymbol{f})^{-1} \boldsymbol{b} \boldsymbol{g}=1
$$

となる。外乱から出力までの伝達関数は $\gamma \rightarrow 0, \tau \rightarrow 0$ に より $H_{y \xi}$ は

$$
\lim _{\gamma \rightarrow 0, \tau \rightarrow 0} H_{y \xi}(s) \rightarrow 0
$$

となるため, 外乱除去特性の効果により, 目標値追従性が 向上する。

また外乱推定值は $H_{\hat{\xi} \xi}$ は

$$
\begin{aligned}
H_{\hat{\xi} \xi}(s)= & \left\{\boldsymbol{c}_{Q}\left(s I-A_{Q}\right)^{-1} \boldsymbol{b}_{Q}+d_{Q}\right\} \\
& \boldsymbol{c}(s I-A-\boldsymbol{b} \boldsymbol{f})^{-1} \boldsymbol{b} \ldots \ldots \ldots
\end{aligned}
$$




$$
\lim _{\tau \rightarrow 0} H_{\hat{\xi} \xi}(s) \rightarrow 1
$$

となり, $\tau$ の選定によって, 特定の周波数 $\omega^{*}$ より小さい $\omega<\omega^{*}$ において $\hat{\xi}$ として外乱 $\xi$ を推定する特性をもつ。

この上式 $(10)(12)$ の 2 つが成立すれば，外乱抑制と外乱 推定両方に良い制御効果を生み出すが，次の 2 つの問題が ある。

1) 制御対象のモデルと誤差式の近似逆系がコントローラ に入るため, コントローラの次数が高くなる。

2) 状態の利用が可能であるか, システムが安定でなけれ ばこの手法は適用できない。前述した手順では状態が 利用できるとして安定化と特性改善を行っている。

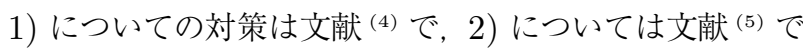
扱われているが，ここでは問題の解決を同時に達成する簡 便な設計法を提案する。

$\langle 2 \cdot 2\rangle$ 反力 (外乱) 推定と内部状態推定のための簡易内 部モデル制御の構成部状態が利用可能であるとき， つぎのブロック線図の構成法 I の制御系を提案する。

ここで, $\Sigma_{f}$ は (4) 式で与えられるシステムで, $\bar{\Sigma}_{f}$ は外 乱のないモデルであるから

$$
\bar{\Sigma}_{f}: \begin{aligned}
& \dot{\overline{\boldsymbol{x}}}=(A+\boldsymbol{b} \boldsymbol{f}) \overline{\boldsymbol{x}}+\boldsymbol{b} \bar{v} \\
& y=\boldsymbol{c} \overline{\boldsymbol{x}}
\end{aligned}
$$

となる。また, $g=\left\{\boldsymbol{c}(-A-\boldsymbol{b} \boldsymbol{f})^{-1} \boldsymbol{b}\right\}^{-1}$ とする。

このとき, 構成法 I の制御系は, 内部モデル制御でコン トローラに近似逆系を用いた場合と同様, 設計パラメータ $\gamma$ の選定により低い周波数の未知入力を再構成するつぎの 性質がある。

性質 1 システム $(A, \boldsymbol{b}, \boldsymbol{c})$ の不変零点が安定で, 内部状 態の利用が可能であるとき $g=\left\{\boldsymbol{c}(-A-\boldsymbol{b} \boldsymbol{f})^{-1} \boldsymbol{b}\right\}^{-1}$ と選 定すれば，構成法 I のシステムは目標值追従について

$$
\lim _{s \rightarrow 0} \boldsymbol{c}(s I-A-\boldsymbol{b} \boldsymbol{f})^{-1} \boldsymbol{b} \boldsymbol{g}=1 \text {. }
$$

が成立し，また， $\gamma \rightarrow 0$ とするとある特定の周波数 $\omega^{*}$ よ り低い周波数 $\omega<\omega^{*}$ の外乱に対し

$$
\hat{\xi} \fallingdotseq \xi
$$

が成り立つ。

証明制御対象 $\Sigma_{f}$ 及びモデル $\bar{\Sigma}_{f}$ の方程式とブロック 線図より

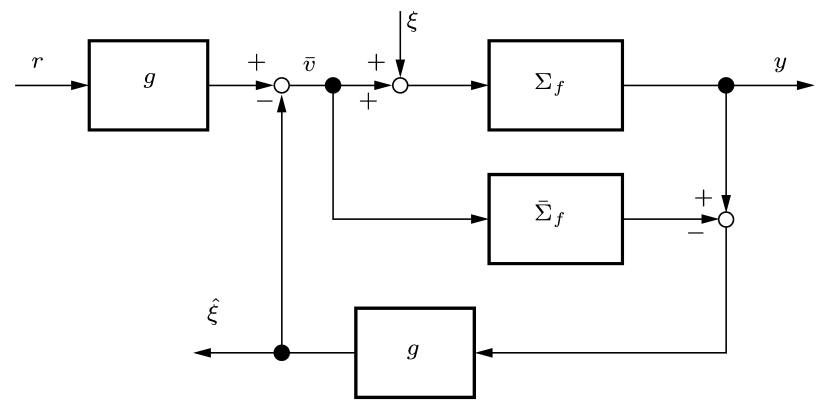

Fig. 2. Proposed Controller Scheme I

$$
\bar{v}=-g \boldsymbol{c}(\boldsymbol{x}-\overline{\boldsymbol{x}})+g r
$$

であるから, $\boldsymbol{x}-\overline{\boldsymbol{x}}=\boldsymbol{e}$ とおいた拡大系は

$$
\begin{aligned}
\left(\begin{array}{l}
\dot{\boldsymbol{x}} \\
\dot{\boldsymbol{e}}
\end{array}\right) & =\left(\begin{array}{cc}
A+\boldsymbol{b} \boldsymbol{f} & -\boldsymbol{b} g \boldsymbol{c} \\
\mathbf{0} & A+\boldsymbol{b} \boldsymbol{f}
\end{array}\right)\left(\begin{array}{l}
\boldsymbol{x} \\
\boldsymbol{e}
\end{array}\right)+\left(\begin{array}{c}
\boldsymbol{b} g \\
\mathbf{0}
\end{array}\right) r+\left(\begin{array}{l}
\boldsymbol{b} \\
\boldsymbol{b}
\end{array}\right) \xi \\
y & =\left(\begin{array}{ll}
\boldsymbol{c} & \mathbf{0}
\end{array}\right)\left(\begin{array}{l}
\boldsymbol{x} \\
\boldsymbol{e}
\end{array}\right) \\
\hat{\xi} & =\left(\begin{array}{ll}
\mathbf{0} & g \boldsymbol{c}
\end{array}\right)\left(\begin{array}{l}
\boldsymbol{x} \\
\boldsymbol{e}
\end{array}\right) \ldots \ldots \ldots \ldots \ldots(15)
\end{aligned}
$$

となる。まず $r$ から $y$ の伝達関数は

$$
\boldsymbol{c}(s I-A-\boldsymbol{b} \boldsymbol{f})^{-1} \boldsymbol{b} g
$$

で, $g=\left\{\boldsymbol{c}(-A-\boldsymbol{b} \boldsymbol{f})^{-1} \boldsymbol{b}\right\}^{-1}$ より，(13) 式が成立する。

また $\xi$ から $\hat{\xi}$ の伝達関数は

$$
g \boldsymbol{c}(s I-A-\boldsymbol{b} \boldsymbol{f})^{-1} \boldsymbol{b}
$$

であり，閉ループ系の極は補題から $\gamma \rightarrow 0$ の極限において 安定な零点と実部が負の無限遠点で, 安定零点は相殺され るから

$$
\begin{array}{r}
\lim _{\omega \rightarrow 0} g \boldsymbol{c}(j \omega I-A-\boldsymbol{b} \boldsymbol{f})^{-1} \boldsymbol{b}=1 . \\
\lim _{\gamma \rightarrow 0} \boldsymbol{c}(j \omega I-A-\boldsymbol{b} \boldsymbol{f})^{-1} \boldsymbol{b} \rightarrow 0 \cdots
\end{array}
$$
となり, これにより, 構成法 I では内部モデルのコント ローラに近似逆系を利用した場合と同等の特性として $\hat{\xi} \fallingdotseq$ $\xi\left(\omega<\omega^{*}\right)$ を有し，コントローラ次数は低減化される。

$\langle 2 \cdot 3\rangle$ 一般化安定化補償器の簡易設計と特性 構成 法 I では制御対象のモデルを利用し, 内部变数を利用可能 とした。後に示す構成法 II (Fig.4) として, 内部状態を必 要としない形に拡張することができる。

制御対象の数式モデルの代わりに，つぎのフルオーダオ ブザーバ

$$
\Sigma_{o b} \quad \dot{\hat{\boldsymbol{x}}}=\left(A+\boldsymbol{k}_{\rho} \boldsymbol{c}\right) \hat{\boldsymbol{x}}+\boldsymbol{b} u-\boldsymbol{k}_{\rho} y \cdot
$$

を導入する。

$$
\text { ここでオブザーバゲイン } \boldsymbol{k}_{\rho} \text { を }
$$

$$
\begin{aligned}
& \boldsymbol{k}_{\rho}=-\rho^{-1} \boldsymbol{c} M \\
& M A^{T}+A M-\rho^{-1} M \boldsymbol{c}^{T} \boldsymbol{c} M+\boldsymbol{b} \boldsymbol{b}^{T}=\mathbf{0}
\end{aligned}
$$

のように選定し, 状態推定值を利用したフィードバック $u=\boldsymbol{f} \hat{\boldsymbol{x}}$ を併用した Fig.3 のブロック線図の構成法を考 え, 未知入力オブザーバを利用した安定化補償器の一般形 を導入する。

ここで，オブザーバの誤差方程式は $\boldsymbol{x}-\hat{\boldsymbol{x}}=\hat{\boldsymbol{e}}$ とすると

$$
\dot{\hat{\boldsymbol{e}}}=\left(A+\boldsymbol{k}_{\rho} \boldsymbol{c}\right) \hat{\boldsymbol{e}}+\boldsymbol{b} \xi
$$

であるので,

$$
\psi=c \hat{e}
$$

を出力として $(20)(21)$ の誤差システムの近似逆システム $\hat{Q}_{o}(s)$ を

$$
\hat{Q}_{o}(s) \boldsymbol{c}\left(s I-A-k_{\rho} \boldsymbol{c}\right) \boldsymbol{b}=(\tau s+1)^{-d} .
$$




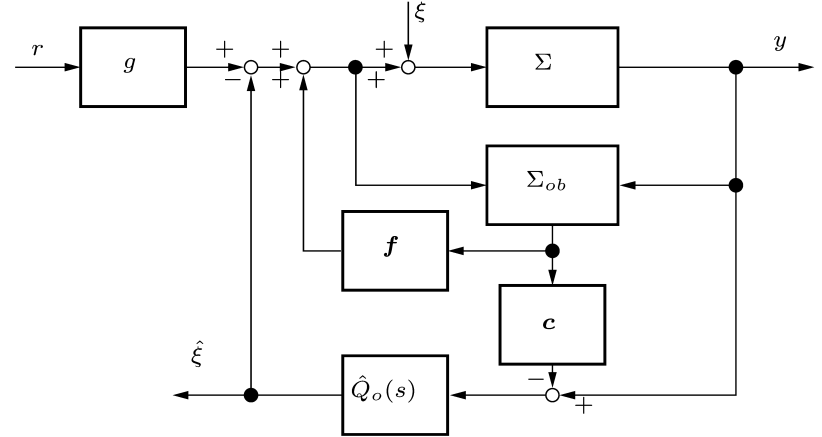

Fig. 3. Full oder observer-based stabilizing controller

を満足するように決定し，その実現を $\left(\hat{A}_{q}, \hat{b}_{q}, \hat{\boldsymbol{c}}_{q}, \hat{d}_{q}\right)$ とす る。これを用いて，Fig.3のような制御系を構成する。

この制御系は一般化安定化補償器の形であり, パラメー 夕を特別に前述のように選定したものであるが，これは内 部モデル制御と同等の性能としてつぎの性質があることが 知られている。

性質 $\mathbf{2}^{(5)}$ ブロック線図の一般化安定化補償器の制御系 は， $(A, \boldsymbol{b}, \boldsymbol{c})$ が最小位相系であるとき， $\rho \rightarrow 0$ とすると，才 ブザーバは未知入力系のオブザーバとなる。また， $\tau \rightarrow 0$ とすると $\hat{\xi}$ は $\xi$ の推定值となり， $\xi$ から $y$ への伝達関数は 零に漸近する。これによって，内部モデル制御と同等の外 乱推定, 外乱除去, 目標值追従特性を持つ。

ここで, $\xi$ から $y$ への伝達関数 $H_{y \xi}(s)$ は

$$
\begin{aligned}
H_{y \xi}(s)= & \boldsymbol{c}(s I-A-\boldsymbol{b} \boldsymbol{f})^{-1} \boldsymbol{b}\left[1-\boldsymbol{c}\left(s I-A-\boldsymbol{k}_{\rho} \boldsymbol{c}\right)^{-1} \boldsymbol{b}\right. \\
& \left.\left(\hat{\boldsymbol{c}_{q}}\left(s I-\hat{A}_{q}\right)^{-1} \hat{\boldsymbol{b}_{q}}+\hat{d}_{q}\right)\right] \\
& -\boldsymbol{c}(s I-A-\boldsymbol{b} \boldsymbol{f})^{-1} \boldsymbol{b} \boldsymbol{f}\left(s I-A-\boldsymbol{k}_{\rho} \boldsymbol{c}\right)^{-1} \boldsymbol{b}
\end{aligned}
$$

となり, (7) 式との差異は最後の項の状態推定による誤差 の影響分だけが異なるが， $\rho \rightarrow 0$ とすることでこの項も零 に漸近するので $H_{y \xi}(s)$ も零に漸近する。

このような構成で，内部状態が既知の制約を緩和できる が，コントローラ次数は内部モデル制御の場合と同じ $(n+d)$ 次である。

そこで，この一般化安定化補償器の制御系に，前節の内 部モデル制御を低次元化した手法を利用した簡易設計法と して，Fig.4のブロック線図の制御系を提案する。ただし， $g=\left\{\boldsymbol{c}(-A-\boldsymbol{b} \boldsymbol{f})^{-1} \boldsymbol{b}\right\}^{-1}, \quad \bar{k}=\left\{\boldsymbol{c}\left(-A-\boldsymbol{k}_{\rho} \boldsymbol{c}\right)^{-1} \boldsymbol{b}\right\}^{-1}$ で ある。

このとき構成法 II について，つぎの性質を得る。

性質 $3(A, \boldsymbol{b}, \boldsymbol{c})$ の不変零点のすべての実部が負 $($ 最小位 相) である。ここで $\rho \rightarrow 0$ とすると構成法 II では，内部状 態を推定すると同時に，性質 2 と同様の低い周波数の外乱 の推定も可能で, 外乱除去特性を持ち, コントローラ次数 はオブザーバの次数と等しい。

証明 $x-\hat{x}=\hat{e}$ と定義したので, ブロック図の拡大状 態方程式は

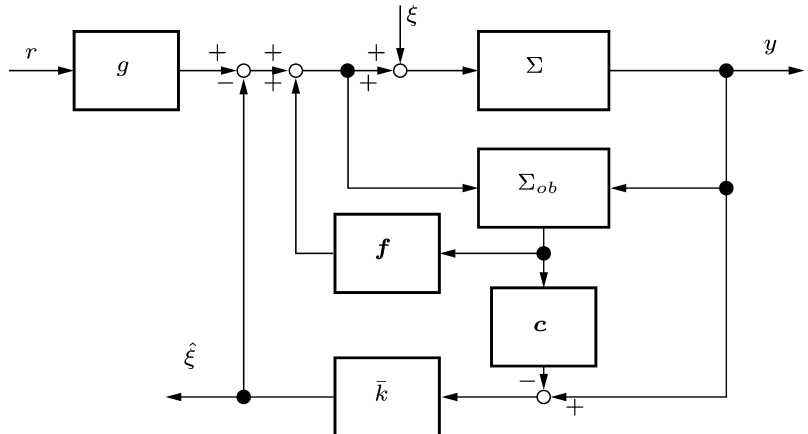

Fig. 4. Proposed Controller Scheme II

$$
\begin{aligned}
& \dot{\boldsymbol{x}}=(A+\boldsymbol{b} \boldsymbol{f}) \boldsymbol{x}-\boldsymbol{b}(\boldsymbol{f}+\bar{k} \boldsymbol{c}) \hat{\boldsymbol{e}}+\boldsymbol{b} \xi+\boldsymbol{b} \boldsymbol{g} r \\
& \dot{\hat{\boldsymbol{e}}}=\left(A+\boldsymbol{k}_{\rho} \boldsymbol{c}\right) \hat{\boldsymbol{e}}+\boldsymbol{b} \xi \ldots \ldots \ldots \ldots \ldots \ldots \ldots \ldots \ldots \ldots \ldots \ldots+\cdots \\
& \hat{\xi}=\bar{k} \boldsymbol{c} \hat{\boldsymbol{e}}
\end{aligned}
$$

である。ここで $\hat{\boldsymbol{e}}$ は $(A, \boldsymbol{b}, \boldsymbol{c})$ のすべての不変零点の実部が 負であるから, 補題の $L Q$ 制御の極限特性の双対から

$$
\lim _{\rho \rightarrow 0}\left(s I-A-\boldsymbol{k}_{\rho} \boldsymbol{c}\right)^{-1} \boldsymbol{b} \rightarrow 0 .
$$

が成立する。これより (18), (19) は $\rho \rightarrow 0$ で

$$
\lim _{\rho \rightarrow 0} \hat{e} \rightarrow \mathbf{0}
$$

が成立し，未知入力系のオブザーバとなる。また $\hat{\xi} は$

$$
\hat{\xi}(s)=\bar{k} \boldsymbol{c}\left(s I-A-\boldsymbol{k}_{\rho} \boldsymbol{c}\right)^{-1} \boldsymbol{b} \xi(s) .
$$

となるので, $L Q$ の極限特性の双対から, $\rho \rightarrow 0$ と選定す ると, 性質 1 と同様の性能, すなわち, ある周波数 $\left(\omega^{*}\right)$ 上 $\eta$ 低い周波数 $\omega<\omega^{*}$ の外乱に対して

$$
\hat{\xi} \fallingdotseq \xi
$$

が成立し，低い周波数の未知入力の再構成ができる。

外乱から出力までの伝達関数 $H_{y \xi}$ は

$$
\begin{aligned}
H_{y \xi}(s)= & \boldsymbol{c}(s I-A-\boldsymbol{b} \boldsymbol{f})^{-1} \boldsymbol{b} \\
& \left\{1-\bar{k} \boldsymbol{c}\left(s I-A-\boldsymbol{k}_{\rho} \boldsymbol{c}\right)^{-1} \boldsymbol{b}\right\} \\
& -\boldsymbol{c}(s I-A-\boldsymbol{b} \boldsymbol{f})^{-1} \boldsymbol{b} \boldsymbol{f}\left(s I-A-\boldsymbol{k}_{\rho} \boldsymbol{c}\right)^{-1} \boldsymbol{b}
\end{aligned}
$$

であるから，一般化安定化補償器で近似逆系を構成した場 合の $(23)$ と類似の伝達関数となるので, 外乱抑制効果も同 じである。

このように構成法 II では，内部モデル制御と同等の低周 波数外乱 (入力) の再構成機能を持ち, コントローラ次数は 対象の次数と同じ $n$ 次元で，しかもオブザーバは未知入力 系の状態推定を達成するから，内部モデル制御や構成法 I のように状態が既知，あるいは対象が安定であるという制 約は不要となり，問題 1)，2）に対する解決策を得たことに なる。

\section{3. ワイヤ駆動方式把持機構への応用}

〈3・1〉把持力制御の為のシステム 人が物を掴んで持 


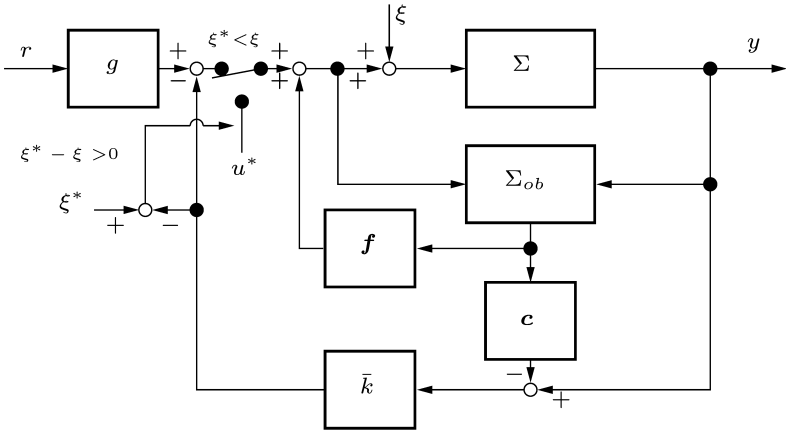

Fig. 5. Proposed Controller Scheme II for Grasping Control

ち運びするとき, 物体を握り潰さずかつ適切な力で把持し ている。堅く重いものと, シュークリームやバームクーへ ンのように軽くて軟らかいものとを掴む場合，対象を認識 し, 先験的な経験則に従い力を加減し把持する機能と, 触 れたときの感触から力を加減しながら把持する機能の 2 つ があると考える。ここでは，前者の機能を自動化するシス テムを, 前章で展開した一般化安定化補償器の簡易設計法 を利用して構成し，実験によりその有効性を示す。

把持機構は, ワイヤ駆動方式の 2 指 2 リンクマニピュレー タとして，把持力を加減するシステムは，提案した制御系 を利用した Fig.5のような制御系とする。ここで，物体に 応じて設定する把持力 (反力) $\xi^{*}$ は，あらかじめ物体に応 じた適正な把持力をデータベース化しておき，カメラ等の 画像情報等から物体を認識し，その物体に応じた設定值を 引き出し $\xi^{*}$ と選定するとして，ここでの実験では $\xi^{*} の$ 設 定值が決定されたものとして行う。目標值 $r$ は把持できる ワイヤの巻き取り量を与え, Fig.5の制御系で把持動作を 行う。物体に接触するまではワイヤを巻き取り，マニピュ レータが物体に接触すると反力 $\xi$ が徐々に増大していく。 ここで, この $\xi$ の推定值 $\hat{\xi}$ と設定值 $\xi^{*}$ との比較により, 反 力と把持力が $\hat{\xi}=\xi^{*}$ となった段階で制御入力を $u^{*}\left(\hat{\xi}=\xi^{*}\right.$ となった時点でのトルク）に固定することで，対象物に応 じた力で把持するシステムを提案することができる。この 制御系の最も特徵的な点は力に関するセンサを必要としな い点である。

〈3·2〉 ワイヤ駆動方式 2 指 2 リンクマニピュレータと そのモデル マニピュレータの機構は文献 (7) の差動機構 を応用する。これは 1 つの入力を 2 つの出力端に分岐する もので Fig.6 の機構である。Fig.6のリンク 2 の $\alpha$ の部分 に一端を固定したワイヤ (一点鎖線で表記) を，回転自在に なるように装着されたプーリ 2 に反時計回りに 1 回巻き付 ける。同様にプーリ 1 , プーリ0の順にワイヤを同一回転 方向に巻き付け, 最後にワイヤの一端をモー夕軸に固定す る。この時, 張力 $f$ を与えると各リンクにはプーリ半径に 応じたトルクが発生する。ここで，プーリ1，プーリ 2 の 半径を $r_{1}, r_{2}$ と置くと, 各リンクに発生するトルクは次式 で求められる(7)。

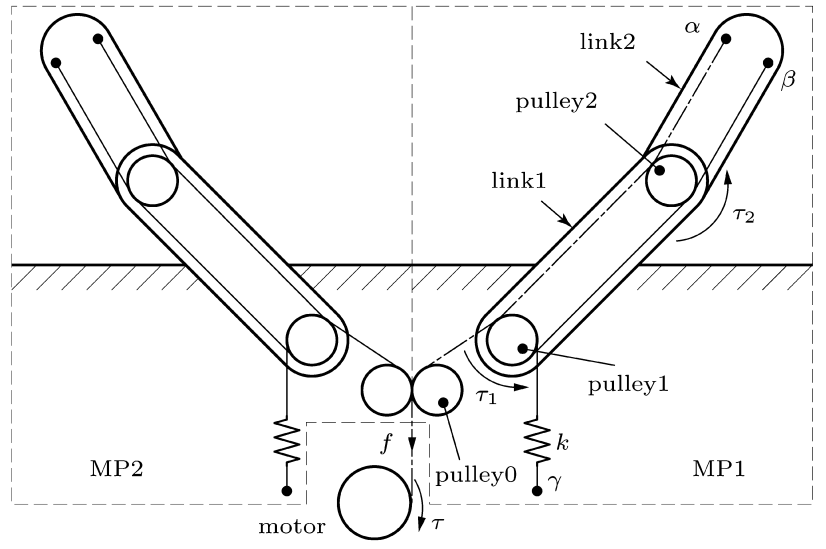

Fig. 6. Tendon-Driven Mechanism for Robotic Hand

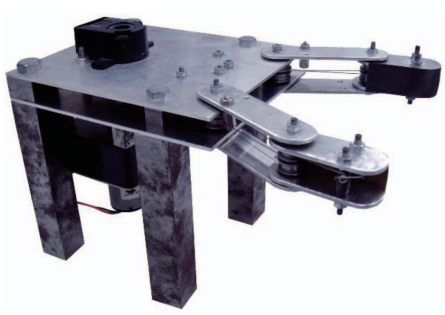

Fig. 7. Prototype Robotic Hand with Two Fingers

$$
\tau_{1}=f r_{1} \quad \tau_{2}=f r_{2}
$$

(29) 式よりワイヤ 1 本で 2 つのリンを動かすことが可能 である。

前述の機構に，リンクの外側に動作後の指が初期位置に 戻るためと, 張力維持のためにバネ $k$ を付加したワイヤを 取り付ける。外部のワイヤは $\beta$ の部分に一端を取り付け, プーリ2,プーリ1の順に時計回りに 1 回ずつ巻き付け, バ ネを付加し $\gamma$ の部分で 1 端を固定する。これにより 1 つの モータで 2 本の指を動作させ, 対象物を把持させる機構で ある。この機構は, モー夕を逆転させることでバネにより 元の状態に復元する。また, Fig.6 を基に試作したマニピュ レータを Fig.7 に示す。

急激な把持動作を行うことを考えず，ゆっくりとした把 持を想定し慣性モーメントを無視すると, このワイヤ駆動 の把持システムは Fig.8のようなモデルで表現できる。こ こでモータトルク $\tau$, 回転角 $\theta$ やワイヤの変位 $x$ を定義す ると

$$
\begin{aligned}
& \tau=f r \\
& f=c \dot{x}+k x \\
& x=r \theta
\end{aligned}
$$

で, $x_{1}+x_{2}=x, \quad \theta=\theta_{1}+\theta_{2}$ であり $x_{1}=x_{2}$ より

$$
2 c r^{2} \dot{\theta}+2 k r^{2} \theta=\tau
$$

なる運動方程式となる。 


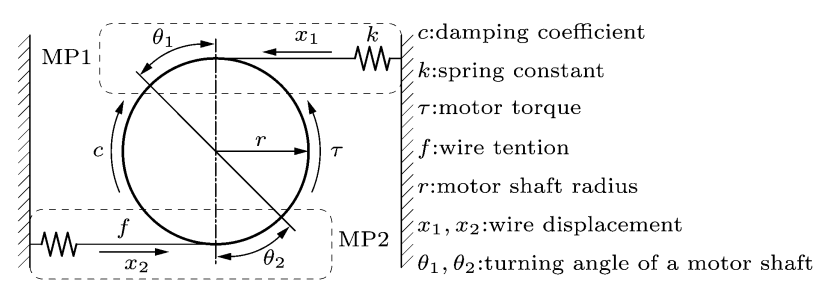

Fig. 8. Model of Robotic Hand with Two Fingers

Table 1. Physical Parameters

\begin{tabular}{|c|c|}
\hline$c[\mathrm{Ns} / \mathrm{mm}]$ & 8.40 \\
\hline$k[\mathrm{~N} / \mathrm{mm}]$ & 0.20 \\
\hline$r[\mathrm{~mm}]$ & 4.5 \\
\hline
\end{tabular}

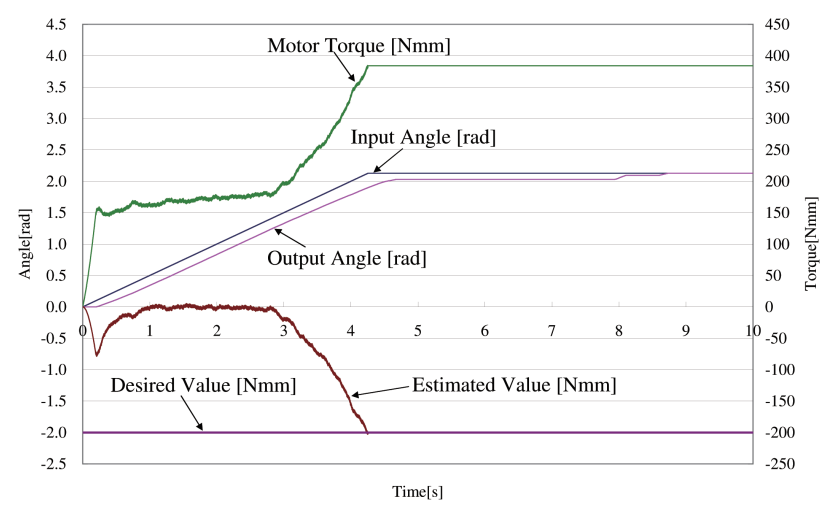

Fig. 9. Experimental Result : Proposed Controller SchemeII

\section{4. 実験による評価と検証}

前節で導入した運動モデルに対し，各々の物理パラメー 夕の測定值を Table 1 のように求め, このモデルから制御 系をFig.8のように構成し実験を行った。本実験では，本 手法を用いて設定する把持力 (目標值)に追従して把持制御 が可能か確認する。

構成法 II による把持制御実験結果を Fig.9 と Fig.11に 示す。Fig.9 は把持力を $\xi^{*}=-200[\mathrm{Nmm}]$ (内容物の入っ たペットボトルを把持できる力), Fig.11 はバームクーヘ ンを適切に把持する力として $\xi^{*}=-25[\mathrm{Nmm}]$ と設定して いる。

どちらの実験においてもフィードバックゲインは重み係 数が $\gamma=10^{-6}$ で $\boldsymbol{f}=-992.1$ とし，オブザーバゲインは重 み係数が $\rho=10^{-7}$ で $\boldsymbol{k}_{\rho}=-9.5$ としている。どちらの場 合もバームクーヘンを対象物として把持させている。また, Input Angle はモータシャフトの目標回転角度で, Output Angle はそれをロータリエンコーダにより測定したもので ある。

Fig.10は設定值を $\xi^{*}=-200[\mathrm{Nmm}]$ とした場合の実験 の様子であるが，マニピュレータがバームクーヘンを大き く変形させていることがわかる。

一方，設定值を $\xi^{*}=-25[\mathrm{Nmm}]$ とした場合の実験であ る Fig.12 を見ると，大きく変形させずに適切な把持が行わ れていることがわかる。この場合の実験結果である Fig.11

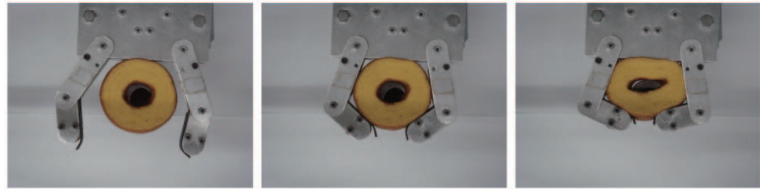

Fig. 10. Unsuccessful result

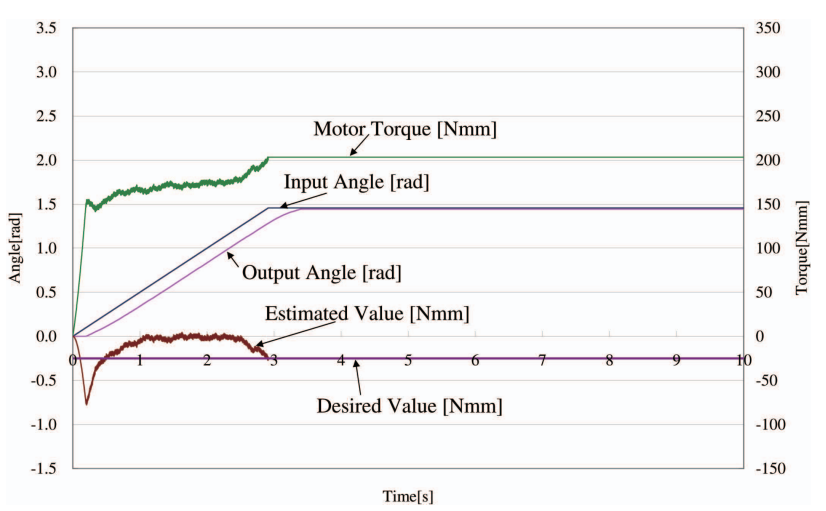

Fig. 11. Experimental Result : Proposed Controller SchemeII
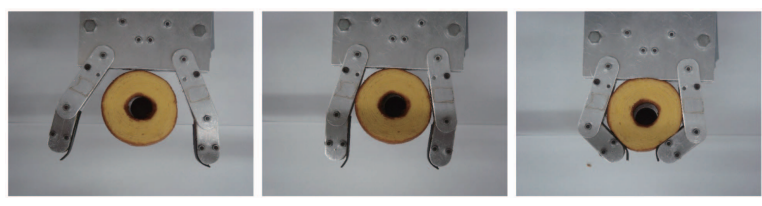

Fig. 12. Successful result

をみても, モータシャフトの回転角度が $1.4[\mathrm{rad}]$ 程度でとど まっており，設定值 $\xi^{*}$ を適正な值に設定することで，バー ムクーヘンなどの軟らかい物体を大きく変形させず把持す ることができる。

本手法の推定特性の精度をさらに向上させるため, 力セ ンサー等によるセンサ測定值との比較，検討実験が今後必 要な課題である。

\section{5. おわりに}

本研究では, 従来の内部モデル制御の問題点であったコ ントローラ次数の増大という問題と, 内部状態の利用が可 能という制約を解決するため, 内部モデル制御の簡易設計 手順を導入し，この手法をオブザーバにもとづく一般化安 定化補償器による制御に展開し, 新しい簡易な設計法を提 案し, その有効性をマニピュレータによる把持力制御実験 により検証した。

この簡易設計手順により構成した制御系が，従来の内部 モデル制御と同じ目標值追従特性と未知入力推定特性を持 つことを示し，さらにこれを拡張し把持に適した新しい制 御系を提案し, 実験により有効であることを示した。指に かかる反力が一定であるという限定条件はあるものの，指 の根本部が動かない静的な把持や, 重力や慣性力の影響が 少ない状況下の把持において, センサーレスで把持制御を 実現できることを，本研究で明らかにした。 
本研究では 1 入出力系について述べた。本理論の多入出 力系への拡張による一般化についての結果も見通しを得て おり，今後明らかにする予定である。

本研究の一部は, 文部科学省科学研究費補助金基盤研究 (C) (No.21560476) によるものである。

(平成 21 年 3 月 17 日受付, 平成 21 年 7 月 14 日再受付)

\section{文献}

(1) M. Morari and E. Zafiriou: "Robust Process Control", Prentice Hall (1987)

(2) K. Zhou and Z. Ren: "A New Controller Architecture for High Performance, Robust, and Fault-Tolerant Control", IEEE Trans. Automatic Control, Vol.46, No.10, pp.16131618 (2001)

(3) N. Kobayashi, M. Sakurai, T. Nakamizo, and Y. Yano: "The Limiting Form of Optimal Regulations and Disturbance Decoupling Problem", Trans. SICE, Vol.34, No.6, pp.563-570 (1998) (in Japanese)

小林伸明・櫻井光広・中溝高好・矢野靖仁：「最適レギュレータの極 限形式と外乱分離問題」, 計測自動制御学会論文集, Vol.34, No.6, pp.563-570 (1998)

(4) Z. shu, K. Watanabe, and K. Yamada: "Unification of Model and Compensation of Internal Model Control", Trans. SICE, Vol.31, No.8, pp.1030-1036 (1995) (in Japanese)

舒 志斌・渡部慶二・山田 功:「内部モデル制御系のモデルと補償器 の一体化」, 計測自動制御学会論文集, Vol.31, No.8, pp.1030-1036 (1995)

(5) M. Tani, R. Suzuki, D. Yamashita, and N. Kobayashi: "Generalized Internal Model Control with Servo Compensation Using a Reduced Order Observer", textitTrans. SICE, Vol.42, No.9, pp.1027-1034 (2006) (in Japanese) 谷 正史・鈴木亮一・山下大輔・小林伸明：「低次元オブザーバを利 用したサーボ特性をもつ一般化内部モデル制御の構成法」, 計測自 動制御学会論文集, Vol.42, No.9, pp.1027-1034 (2006)

(6) R. Suzuki, T. Miyazaki, and N.Kobayashi: Decoupling Control via All Stabilizing Control with Limiting Properties of LQ Control and Its Application to A Mechanical System, IEEE Conference on Control Applications, pp.412-417 (2001)

(7) S. Hirose amd S. Ma: "Development of Tendon Driven MultiJoint Manipulator Based on Coupled Drive", Trans. SICE, Vol.26, No.11, pp.1291-1298 (1990) (in Japanese)

広瀬茂男・馬 書根:「ワイヤ干渉駆動型多関節マニピュレータの 開発」, 計測自動制御学会論文集, Vol.26, No.11, pp.1291-1298 (1990)

（非会員） 1999 年北陸先端科学技術大学院大学 情報科学研究科博士前期後期課程修了。日本学術 振興会研究員を経て, 現在, 金沢工業大学工学部 ロボティクス学科 准教授。博士 (情報科学)。

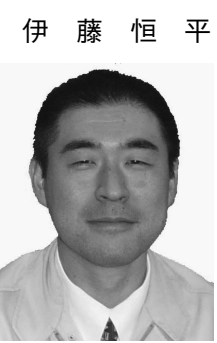

（非会員）1993 年防衛大学校航空宇宙工学教室 修了。同大学校理工学研究科修了。川崎重工業会 社研修員, 防衛庁技術研究本部第 3 研究所勤務 を経て, 現在, 金沢工業高等専門学校機械工学科 教授。

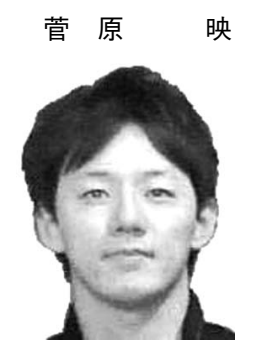

（非会員） 2006 年金沢工業大学工学部機械シス テム工学科卒業。2008 年金沢工業大学機械工学 専攻修了。現在, 綜合警備保障 (株)に勤務。

小 林 伸 明 (非会員) 1971 年防衛大学機械工学科卒業。熊

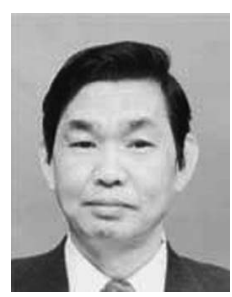
本大学大学院工学研究科修士課程 (機械工学) 修 了。東京工業大学研修生, 防衛庁技術研究本部勤 務を経て, 現在, 金沢工業大学工学部ロボティク 又学科 教授。工学博士。

竹 井 義 法 (正員) 1996 年福岡大学大学大学院工学研究科

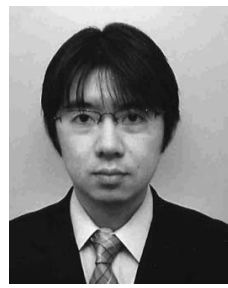
博士課程前期 (電気工学) 修了。九州大学大学院 システム情報科学研究科博士後期課程単位取得後 退学。同助手, 金沢工業大学工学部特別研究員を 経て, 現在, 金沢工業大学工学部ロボティクス学 科 准教授。博士 (工学)。 